\begin{abstract}
This paper renders an account of the rapid institutionalization of the academic field of Communication for Development and Social Change (CDCS) in Spain in recent years following a period of neglect and marginalization. The ongoing expansion of the field of CDSC in the Spanish context is understood as a process of implosion, i.e. a collapse inwards, which results from the inconsistencies and weaknesses of fast and late institutionalization. The methodological approach for this inquiry is a documental review of both academic literature and research and institutional reports produced in Spain between 1980 and 2010. Based on this review, the paper contrasts the trajectory of the field in Spain with the debates at the international level, establishing relevant continuities and differences.
\end{abstract}

\title{
Keywords
}

Communication for development; communication for social change; Spain; field; institutionalization. 


\section{Communication, Development and Social Change in Spain: A field between institutionalization and implosion}

\section{Introduction}

We witness at present a number of transitions apparent at multiple levels, both in world events and social research. The worldwide financial crisis and the appearance of new forms of social mobilization by active citizens such as e.g. the 15-M movement in Spain and Occupy WallStreet in the US (Castells, 2012) are examples of the former. The advent of new epistemologies within the theorization of the social sciences in the South (Sousa Santos, 2009; Mignolo, 2000; Wallerstein, 2004), and the increasing references to 'communication for social change' instead of 'communication for development', are examples of the latter.

Taking those contextual transitions into account, this paper renders an account of the process of late institutionalization of the field of Communication for Development and Social Change (from now on, CDSC) in Spain, which has only taken place in recent years, following a period of omission and marginalization. This institutionalization is considered 'late' as compared to Latin America, where the debates, theorization and research around CDSC started in the '70s, even if they haven’t been circulated enough in the English language due to lack of translation. It is also 'late' compared to the European and international scene, where the concept of development is currently subject to charged debates and critical revision.

While the boom of CDCS in Spain is related to the increasing social inequality caused by the current crisis, this paper focuses on analysing the field's deficiencies from a historical perspective. Because of those long-standing deficiencies, the ways in which Spanish NGOs and social movements are seeking to address the current crisis via communicative action overlap with an 'implosion' of the field -, that is, a process such that the field appears to be booming but is in fact collapsing inwards as a consequence of the inconsistencies and contradictions characteristic of its institutional development over the years. 
In the past twenty years, the Spanish field of CDSC has gone through three stages. The first stage, characterized by omission and marginalization, was followed by a flourishing phase (from the mid '90s to 2004), in turn succeeded by a period of institutionalization (from 2005 until now). I argue in this paper that this rapid evolution and growth can be analyzed as an implosion, i.e. a collapse inwards, due to the inconsistencies and weaknesses characteristic of the institutionalization period.

Methodologically, these three stages were identified by way of a review of academic literature and the analysis of additional documentation evidencing the emergence and institutionalization of CDSC in Spain not only within academic units, but also in relevant governmental and non-governmental organizations. The literature reviewed includes, in alphabetical order: Barranquero (2009, 2010); Erro (2002); Fernández Viso (2012); Jerez, LópezRey and Sampedro ( 2008); Moragas (2011); CONGDE (2005); Chaparro (2002, 2009, 2013); Chaves (2012); Santolino (2010); González (2007); Meda (2010); Marí (2007, 2011, 2013); and Sierra (2006). Additional documentation was obtained from organizations such as the State Coordination of Development NGOs [Coordinadora Estatal de ONGD], the State Network of Community Media [Red Estatal de Medios Comunitarios, ReMC] and EMA-RTV, the Association of Municipal and Civic Radio and TV Broadcasting Stations of Andalusia.

My starting point, following MacDonald and Tipton (1993), is that, because documentation intends to record the social world, it is thus one of the main methodological components of research -in Erlandson’s words, “a third source of evidence” (Erlandson et. al. 1993: 99). The historiographical perspective that I adopt here takes as its point of departure the fact that the social sciences are themselves historic disciplines (Wright Mills, 1959). In this particular case, I focus on rendering an account of the emergence and trajectory of the field of CDSC in Spain as the basis not only for comparison with the international field, but importantly for the critical formulation of a research agenda for the future.

The question that underlies this inquiry is: if CDSC is the answer, which is the question? Or, 
in other words, which is the link between pressing unsolved sociopolitical questions and the recent institutionalization of CDSC in Spain? How does CDSC compare to other approaches in terms of contributing theoretical tools and communication strategies to the efforts of those social actors who are seeking to transform reality? And moreover, how do the transitions and tensions identified in the field in Spain compare to the history and performance of CDSC at the international and Latin American levels? A comparison of continuities and discontinuities at the national and international level makes it possible to identify the specific characteristics of the field in Spain.

\section{Strategy for the periodization of CDSC in Spain}

Following Enghel (2011), this paper considers communication for development (Servaes, 2007a and 2007b; Lennie and Tacchi, 2010) and communication for social change (Wilkins, 2000; Gumucio-Dagron and Tufte, 2006) as different approaches to naming and characterizing a field pertaining to the role of communication in strategic efforts to overcome collective social problems (Wilkins, 2008).

CDSC is understood here in both academic and practical terms (Gumucio-Dagron and Tufte, 2006) as praxis, i.e. an expression of “men’s reflection and action on the world in order to transform it" (Freire, 1970:23). It is both a reflexive practice and a theoretical construct that leads to action. Given these characteristics, in order to periodize it, it is necessary to look into both the social practices through which CDSC is implemented, and the processes of academic theorizing (an approach based on de Sousa Santos' diatopic hermeneutics; 2009). As regards the practices, I analyze the ways in which development NGOs include and reflect upon communicative matters in their operational strategies, with an eye to the social background -i.e. historical events and mobilizations linked to the operation of these organizations and movements. As regards academia, I look into the theoretical work undertaken by researchers, universities and think tanks devoted to international cooperation in Spain in recent years. More specifically, I analyze the studies of communication research coordinated by Martínez Nicolás ( 2009 and 2011), which identify two 
crucial aspects of the analysis of a scientific community:

1. The historical conditions under which communication researchers do their job, with an eye to the social context (state and evolution of the communicative system), the institutional context (teaching and research centers, publishing outlets, dissemination systems), and the epistemological context (state of the art of a discipline); and

2. The internal structure of the scientific community, with an eye to the provenance, training and epistemological attachments of researchers.

I begin by considering the cycles of social mobilization and the relevant international events that provide a frame for the analysis of the communicative practices of development NGOs and social movements in Spain in the past twenty years: the boom of neoliberal policies in the '80s, the campaign "Fifty years is enough" (1994) ${ }^{1}$, the Seattle WTO protests (1999) and the successive meetings of the World Social Forum since 2001. Secondly, I examine the appearance of NGOs in Spain in the context of the growing prominence of NGOs at the international level, taking into account the ways in which these organizations think about communication (Santolino, 2010;González, 2007; Chaves, 2012).

In the third place, I adopt the stages of communication research in Spain identified by Martínez Nicolás (2011) as the general framework for the analysis of continuities and discontinuities in the study of CDSC. I depart from recent work by Fernández Viso (2012) that studies the origin, evolution and institutionalization of CDSC in Spain from an academic perspective.

\section{Three stages of Communication for Development and Social Change in Spain}

The trajectory of CDSC in Spain can be divided in three stages: pioneer work (from the ' 80 s to 1994), eclosion (1994- 2002) and consolidation and implosion (2003-2011). I characterize and discuss each of them below.

2.1. Pioneer work (from the '80s to 1994) 
In this period, NGOs went from marginality to popularity (Ortega, 1994). Between 1985 and 1988, 28 ONGs were launched. This was a high amount compared to the 23 NGOs that had been instituted between 1947 and 1985. The growth and popularization of NGOs in the '80s, however, did not bring with it attention to the role of communication, which would only gain prominence in the following decade. Several centers and initiatives undertook the task of introducing a communicational dimension to social and solidary action in Spain. In particular, the research centers concerned with 'education for development' played a leading role, reflecting about development and communication in lieu of the scientific community and of the organizations directly involved with communication, as was the case in Latin America and other European countries (see e.g. Pascuali, 1963; Beltrán, 1980; Díaz Bordenave, 1977 among others).

In this period, communicative initiatives in the field of CDSC are scattered and fragmented. The main achievement is the implementation of the Code of Conduct on Messages and Images relating to the Third World, a directive adopted in 1989 by the General Assembly of European NGOs. The Code was put forward in response to the rapid proliferation of images of the Third World that reinforced paternalistic notions of the North as the savior of developing countries considered unable to take responsibility for their own development, and intended to promote reflection about the stereotyped representations embedded in audiovisual content created by many NGOs. In another pioneer initiative, researchers from the Universidad Complutense de Madrid sought to introduce the theoretical and practical experiences from Latin America into the Spanish context via the First Almagro Meeting on Communication and Social Movements, held in 1991, which served as a space for reflection and debate. Additionally, in this period the study of educational communication, particularly the role of the mass media in formal education, progressed. Even if limited to school-related concerns at the time, those studies would eventually lead to an interest in non-formal education among researchers, and in audiovisual and digital literacy among NGOs and social movements.

As regards practice, the Educational Communication Team [Equipo de Comunicación Educativa, 
ECOE], created in Madrid in the '70s, was one of a few solidary organizations to introduce the Latin American communicative approach to their content production and training. ECOE introduced and circulated the theoretical work of Mario Kaplun, the author of the much disseminated book 'A pedagogy of communication' (1998; see also Gumucio-Dagron and Tufte, 2006).

\subsubsection{Eclosion (1994- 2002)}

The year 1994 can be considered a turning point in the field of CDSC in Spain. The 0'7 mobilizations ${ }^{2}$ implied a "before and after" in the coverage of development and cooperation the Spanish media, and would become the object of study of the first rigorous investigations on the matter. As from the '90s, Spanish NGOs became a social actor duly acknowledged by journalists and achieved increasing visibility in the media (Jerez, López-Rey and Sampedro, 2002).

This second stage in the trajectory of CDSC in the country is also linked to two other relevant events besides the 0'7 mobilizations: the Fifth Centennial of the Discovery of America (1992) and the above mentioned campaign "Fifty years is enough” (1994). In parallel with the grandiose events organized for the official celebration of the centennial, a series of meetings of solidary movements denounced the discovery as a colonial cover-up. The campaign "Fifty years is enough” gave rise to Nodo50, a counter information collective that provided Internet services to social movements. The start-up of Nodo50 would play a crucial role in terms of promoting communicational initiatives and triggering studies on social movements' strategies to appropriate the Internet. As already discussed for the case of 'education for development', this was not CDSC strictly speaking, and thus is accounted for here as a subsidiary approach.

In this period, a variety of social actors strengthened their role in advancing CDSC in Spain. In 1997, EMA-RTV organized the First International Congress of Local, Public and Alternative Radio and TV Broadcasters, coordinated by Professor Manuel Chaparro (2004, 2009 and 2012). Created in 1984, EMA-RTV became a node for the collection and dissemination of studies and 
experiences in the field of CDSC. The First Congress was followed by two others (Jerez, 2000; Cádiz, 2002).

Also in 1997, the Communication Institute [Instituto de Comunicación, Incom] was created at the Universidad Autónoma de Barcelona, under the direction of Miquel de Moragas $^{3}$ (2005, 2011). The UNESCO Chair in Communication, which had existed since 1990, was strengthened by the Institute's support, going on to foster research exchanges with a number of international experts in several disciplines, including development and communication. The Master’s program in Media, Communication and Culture promoted by the UNESCO Chair became an academic space for the expansion of research in communication, development and social change.

As regards research, in this period a number of relevant investigations were conducted by Víctor Sampedro (Universidad Rey Juan Carlos), Ariel Jerez (Universidad Complutense de Madrid) and José López-Rey (Universidad de La Coruña). In 1997, the publication “NGOs, mass media and public visibility: citizens vis-à-vis the mediatization of social messages” (2002) analyzed the communication departments and communicative strategies of the 88 NGOs that were members of the State Coordination of Development NGOs [Coordinadora Estatal de ONGD], differentiating between 'conflict' and 'managerial' organizations. According to the authors, conflict-type NGOs “prioritize messages that challenge political representatives and citizens, raising maximalist longterm claims” (ibid, p. 254), while managerial-type NGOs “replace maximalist claims with incremental short-term reforms that can simplify their operations and improve their competitiveness in the search for resources in the charity marketplace” (ibid, p. 255). The authors' conclusions proved to be true over time: today, the NGOs linked to the business world take advantage of their resources and the media's rationale via social marketing, while those linked to official and transnational institutions focus on humanitarian and crisis projects (ibid, p. 283).

Regarding non-governmental organizations, in 1994 the NGO Centre for Cooperation Initiatives [Centro de Iniciativas para la Cooperación, CIC- Batá] was created in the city of Córdoba, with communication for development and civic communication as its core areas (Running 
head: Communication, Development and Social Change in Spain Sáez, 2010). Since its inception, CIC-Batá played a crucial role in the promotion of CDSC in Spain. In 2000, the Association Air Communication [Asociación “Aire Comunicación”] was created by a group of teachers and students of the Master's program in Educational TV of the Universidad Complutense de Madrid and soon became a pioneer in the field of edu-communication in the country. Although intersectional in nature and not directly concerned with CDSC, this initiative was important in that a number of its members eventually moved to other universities across the country and made important contributions to the field.

\subsection{Consolidation and implosion (2003-2011)}

The processes initiated in the previous stage paved the way for a minimum degree of consolidation of the field of CDSC during this period. The research projects designed and coordinated by Javier Erro Sala ${ }^{4}$ were a step in that direction. In his article "The communicative practices of development NGOs: from marketing communication to the advancement of a communicational view” (2001: 51-72), Erro criticized the instrumental view of communication that

$1 \quad$ The campaign was organized in response to the institutions arising from the Bretton Woods Agreement -the World Bank, the International Monetary Fund and the General Agreement on Tariffs and Trade.

2 The 0'7 movement is named after the declaration signed in 1970 by Member States of the United Nations agreeing to raise official development assistance to $0.7 \%$ of donors' national income. Source: http://www.oecd.org/dac/stats/45539274.pdf (Accessed in September 2014).

3 Miquel de Moragas was one of the first Spanish researchers ever to attend one of the conferences of the International Association for Media and Communication Research (IAMCR), together with Manuel Parés y Maicas, in 1976. See Parés y Maicas, M. (1981).

$4 \quad$ After working as a journalist for more than a decade, in the mid-'90s Javier Erro joined the Communication Department of the Universidad José Simeón Cañas in El Salvador. Early in 2000 he returned to Spain, where he worked a series of influential research projects on communication, education and development published by the Development University Institute of the Universidad del País Vasco and the State Coordination of Development NGOs. 
underlies the dominant communicational practices of NGOs, which is aimed at achieving an economic benefit (via fundraising) and/or attracting volunteers. As a consequence of that view, communication's potential to foster social and educational processes aimed at building the social tissue and promoting cooperation and solidarity is displaced and disregarded.

Erro further worked with Teresa Burgui (see Burgui and Erro, 2003) in the Communication Area of the Peace and Third World Foundation [Fundación Paz y Tercer Mundo] to organize the I and II Communication, Education and Citizenship Forum (2006 y 2007), which acted as a meeting point for people working with social communication and education, and made it possible to identify and share novel media and ICT-driven experiences aimed at fostering citizenship. Researchers, journalists, citizens and organizations involved in the advancement of CDSC in Spain came into contact in these Fora.

Also during this period, the books in the trilogy Communication, Development and NGOs (2002), Descovering and developing processes of social communication ( 2003) and The communicational situation of NGOs in the Basque Autonomous Community (2003) brought into the picture an analysis of the communicational practices of development NGOs in Spain from the distinct perspective of CDSC instead of resorting to political communication, public opinion, educommunication or political economy approaches.

Research and communicational approaches during this period were influenced by the mobilizations against the Irak war (2003) and the environmental and social disastrous consequences of the sinking of the oil tanker "Prestige” off the coast of Galicia (2003), as well as the attacks to the Atocha train station in Madrid prior to a general election (2004). As was the case in other countries affected by especially significant events with a high impact on society (e.g. the crisis in Argentina in 2001), a series of techno-communicational practices arose, and a number of empirical investigations sought to analyze them. In 2004, the 11-M and 13- $\mathrm{M}^{5}$ resulted in consequential communication research in Spain. While the 0'7 mobilizations in 1994 had been a stepping stone to empirical research on the communicational practices of NGOs and social movements, the 11-M and 
13-M implied the emergence of a process that reached its high point with the 15-M mobilizations in 2011.

At the very start of this period, in 2003, the participatory action research project "How to incorporate ICT in Andalusian social movements” (Running head: Communication, Development and Social Change in Spain Sáez, 2004 and 2007) explored the strategies for the social and technological appropriation of ICT (particularly the Internet) among twenty representative organizations. The project, framed conceptually within CDSC, linked a number of researchers, activists and organizations who were making strides in the field, leading to the publication of “Everybody owns the Net: appropriation by social movements” (2004).

In 2005, EMA-RTV organized the V Congress of Local, Public and Alternative Radio and TV Broadcasters to coincide with its 20th anniversary and the 25th anniversary of the MacBride report, published by UNESCO in 1980, which was a milestone in the international history of CDSC. The Congress was instrumental in introducing and disseminating in Spain the work of CDSC practitioners and scholars from Latin America, France and Italy such as Rosa María Alfaro (Peru, see ibid 1993), Alfonso Gumucio-Dagron (Bolivia, see ibid 2005), Jean-Jacques Cheval (France, see ibid 1997) and Giuseppe Richieri (Italy, see ibid 1985). Also during this period, the Inter-University Institute of Social Development and Peace [Instituto Interuniversitario de Desarrollo Social y Paz, IUDESP], created in 2006 at the Universidad de Alicante, emerged as an institution that would become relevant for the field (Nós, 2013).

As regards contributions at the academic level, the multi-disciplinary research group "Compolíticas” was created at the Faculty of Communication of the Universidad de Sevilla,

\footnotetext{
5 The denomination 13-M stands for 13 March 2004, the date prior to the 14 March elections, when large mobilizations opposing the Popular Party took place across Spain. Protesters called for governmental transparency regarding the perpetrators of the Atocha attacks on 11 March, when 191 people were killed and more than 1.800 people were injured.
} 
directed by Francisco Sierra Caballero (2006), focusing on 'Communication, development and social change' as one of its research themes.

As regards communicational work undertaken by activists, in 2005 the State Network of Community Media (ReMC) is created as a space that brings together, coordinates and advocates a diversity of media outlets, initiatives and citizen communicational practices under the umbrella of the Communication Third Sector. In 2009 the Network becomes a federation of TV and radio community media from all over the country -some of them in existence since the return to democracy in the late '70s. The federation gave greater visibility to these media.

Additional communicational activity is furthered by the Coordination of Spanish Development NGOs [Coordinadora de Organizaciones No Gubernamentales de Desarrollo de España, CONGDE]. The “CONGDE report on social perception of Development NGOs: this is how they see us” (2005) analyzed citizens’ perception of the image of Development NGOs as regards their work, funding sources and cooperation policies. The study showed on the one hand a high degree of trust on the work done by Development NGOs (above 85\%), and on the other hand a profound unawareness of the amount of Official Development Assistance channeled via these organizations: citizens tend to think that it is much higher than it actually is.

A key event in the process of institutionalization of CDSC in Spain was the 2010 Congress of the Spanish Association of Communication Research [Asociación Española de Investigación en Comunicación de 2010, AE-IC], focused on the theme Communication and Development in the Digital Era, with international researchers from the field such as Rafael Obregón (2014) and Thomas Tufte (2005) in attendance. From then on, academic initiatives that analyze communication in the non-profit sector and/or emphasize development from a CDSC perspective have multiplied. Towards the end of 2011, the RealCode Network [Red Europa América Latina de Comunicación y Desarrollo] was created to link research groups from Europe and Latin America working with communication and development. But the event that made waves was undoubtedly 
the mobilization around 15-M, in May 2011, which led to a large amount of scientific articles and research projects analyzing the phenomenon from a communicational perspective ${ }^{6}$. At this point, the institutionalization, popularity and implosion of the field of CDSC in Spain intersected.

\section{The three stages in review}

The analysis of the three stages historicized above unveils a number of central ideas regarding the emergence, booming and institutionalization of CDSC in Spain. Notably, a number of institutions, fields of knowledge and disciplines not directly connected to the epistemological framework of CDSC at the international level become increasingly subsidiary. This is the case with ‘education for development', educational communication, political communication and public opinion. In this first period, CDCS actions in Spain were driven primarily by NGOs, which were 1) the only organizations that were working on issues related to development, cooperation and international aid at the time, and 2) the first organizations to incorporate information and communication professionals to their structures. As from the early 2000s, CDSC-related work was also carried out by social movements that converged with NGOs and active citizens in social processes such as the public condemnation of the Iraq War (2003), the civic mobilisation in response to the terrorist attacks at the Atocha Station in Madrid (2004), or the most recent demonstrations of the Indignados movement (2011).

Secondly, there is a remarkable gap between the field's advancement in Spain and its growth in other contexts, be them geographically or culturally proximate, as is the case with the rest of Europe and Latin America respectively. This gap may be partly the consequence of academic study programs in Spain, which tend to be organized with a focus on journalism rather than on social

\footnotetext{
6 See $\underline{\text { http://datanalysis15m.wordpress.com/ }}$
} 
communication. No rigorous empirical research focusing on CDSC was undertaken in Spain until the late '90s, when the above mentioned work by Erro was published (2001, 2002 and 2003). The gap is also manifested vis-à-vis communication research at large: while according to Martínez Nicolás(2009) communication research consolidated its position between 1980 and 1995, this did not happen with CDSC until 2003. Third, there is a lack of academic spaces for the appropriation at country level of the international debates pertaining to CDSC, compounded by the absence of sufficient solid investigations accounting for the history of CDSC in Spain. Absent those spaces, debates take place outside university, driven by activist organizations although they involve academic researchers. Fourth, relationships with leading academics and practitioners in the international scene develop at a late stage, and tend to be sporadic and weak. Notably, the appropriation of work by Latin American theorists, researchers and practitioners is marginal and tardy. Indeed, Spanish communication schools could have been linked to Latin American and European CDCS researchers. However, this has not happened historically. Latin American authors have accessed the English-speaking academic world directly, without the mediation of Spain. That was the case of the founders of the CDCS field, specially Luis Ramiro Beltrán.

The causes of the marginal presence of Latin American researchers in the field of CDCS in Spain are diverse, and analysing them exceeds the limits of this paper. Suffice it to say that, as noted by Gumucio (2006), their marginalization is related to the dominant orientation of schools of journalism and departments of communication, which in Spain have historically focused more on the transmission of information paradigm (McQuail, 2010) than on social communication.

Despite these shortcomings, in recent years a number of academic publications have looked into the state of the art of CDSC in Spain, be it from the perspective of alternative communication and media (e.g. Barranquero, 2009 and Barranquero and Sáez, 2010) or from an academic understanding of CFSC (Fernández Viso, 2012). 


\section{Communication for Development? Communication for Social Change?}

\section{Conceptual debates at the national and international level}

The characterization and analysis of the institutional trajectory of CDSC in Spain in turn enables a comparison with the international scene (Ogan, 2009). This comparison focuses on 2006, when critique of the denomination communication for development peaked in international fora, paving the way for the designation communication for social change. Paradoxically, this shift at the international level concurs with the institutionalization of CDSC in Spain. Or in other words, while in Spain academics are jumping on the CDSC bandwagon, international scholars are giving reasons for detaching their work from what they argue is a restrictive framework.

As stated by Gumucio-Dagron and Tufte (2006), Enghel (2011) and Chaparro (2013), the term communication for social change gained traction following the Bellagio Statement on the Role of Communication in Meeting the Millennium Development Goals, issued in 2004 by a group of representatives from bilateral, multilateral and non-governmental organizations following a meeting held in Bellagio, Italy, organized by the Communication for Social Change Consortium with the support of the UK's Department for International Development (DFID). In October 2006 the First World Congress on Communication for Development (WCCD), organized jointly by FAO’s ComDev team, the World Bank and The Communication Initiative, was held in Rome, taking up the Bellagio discussions and seeking to forward an alternative denomination for communication for development.

According to Chaparro (2013:77), the term social change ended up prevailing in those discussions, "though enthusiasm was lacking, because what the new term contributed was not clear, and whether a shift was necessary was not clear either: social change was for development!” Despite the attendance and participation of critical researchers, the WCCD did not allow for the inclusion of the preparatory debates held at regional level, and disregarded many individual contributions. The lack of enthusiasm noted by Chaparro (ibid) may have been the consequence of the lack 
of innovation in the conclusions achieved -most of the Congress's recommendations were similar to those issued at the United Nations' Roundtable on Communication for Development held in Rome, Italy in 2004 (da Costa 2007, quoted in Enghel 2011).

Following Chaparro (2013: 77), I argue that the purpose designated by the new denomination, i.e. 'social change', is problematic inasmuch as it is not qualified, and thus can be promoted in several directions within a wide ideological spectrum. Several communication theorists (Moragas, 2011; Mc Quail, 1991 Mattelart, 1998, Morris, 2003) substantiate social change from diverging perspectives, such as e.g. mass communication research or critical theory. As a consequence, it is necessary to establish the origin and active meanings of the term in order to bring to the fore the agendas underlying in the various understandings. This need resonates with Karin Wilkins' (2009) proposition that the term 'social change' must be problematized as much as 'development'.

In the current context of crisis in Spain, this ambiguity carries over to the problem of specifying what kind of social change is being demanded by particular social actors is. In order for the change demanded to connect with the CDCS tradition, it would need to have at least the following two characteristics: 1) an impact on the economic and political structures that stand in the way of greater social justice and 2) the bottom-up involvement of active citizens and civil society organizations as promoters and protagonists.

Continuing with the historical revision, The Bellagio and WCCD debates are taken up in Spain in the International Forum on Communication, Development and Social Change organized by EMA-RTV in Seville in 2008, where the limitations of the term 'development' were discussed by Spanish researchers in direct dialogue with Latin American experts involved in international forums such as Alfonso Gumucio-Dagron and Amparo Cadavid. The Forum identified the need to problematize the dominant meanings proposed by the mass media and system of thought. At present, the debate and problematization of both 'communication for development' and 
'communication for social change' in Spain is being led by Chaparro, who discusses the matter in his latest book : “development has a long history of transvestism, and it should not use new clothes as camouflage in its attempt to self-perpetuate once it has been sufficiently described” (2013: 72).

Ultimately, debating a choice between 'communication for development' and 'communication for social change' is sterile, in that both terms are inadequate and insufficient to tackle problems of a sociopolitical nature (Enghel, 2011). From this perspective, the debate can be considered yet another manifestation of the limits faced by critical social scientists in advanced societies when it comes to facing the dominant system of thought. As noted by Sousa Santos (2009), at present the critical social sciences are relegated to the role of derivative theories: while substantial theorization is framed by the nouns proposed by the dominant system of thought, be them development or democracy, critics can only qualify the nouns imposed in an attempt to limit their destructive force, thus referring to e.g. human or sustainable development, and to participatory democracy.

Yet, in the process of debating a transition from one term (or paradigm?) to another, alternative concepts emerge: born from indigenous systems of thought that differ from Western thinking, terms such as ‘buen vivir’ or Sumak Kawsay in Quechua, or ‘vivir bien’ or Suma Qamaña (in Aymara) refer to the idea of collective living well, or well-being. For Alberto Acosta (2011), this concept, which is still under construction at the convergence of academic reflection and social movement practices, proposes the recovery of knowledge held by indigenous peoples as a reaction to conventional development. According to Acosta (ibid: 442), the concept “departed from conventional Western ideas of progress, and pointed towards another understanding of the good life, including special attention to nature. Even though 'buen vivir' cannot be connected to Western wellbeing in a simplistic way, it does not reject certain contemporary contributions of Western knowledge, particularly those of critical and nonconformist movements such as environmentalism or feminism”.

Following Acosta (ibid), I suggest that it is possible to contribute to the theorization and 
dissemination of alternative views by bridging the contributions of indigenous worldviews, such as the Quechua and the Aymara, and those of Western critical theories, in that both distance themselves from the economic, Eurocentric and patriarchal approaches to development and social change. I see an opportunity for establishing connections between the critique of dominant approaches to communication for development put forward in previous historical periods both by Latin American critical researchers of media and education such as Bordenave, Beltrán, Freire, Kaplún, Pascuali or de Melo and by pioneers in the critique of economic approaches to development such as Nerfin (1977) or Max Neef (1991), and the new propositions arisen from indigenous movements.

\section{If communication for development and social change is the answer, what is the question?}

All things considered, the problem that remains is: if communication for development and social change is the answer, what is the question? Or in other words, what is it that makes communication for development and social change the most appropriate theoretical approach to tackling sociopolitical problems compared to other approaches adopted by development NGOs and social movements? Along these lines, Enghel (2012) poses a series of questions in order to address the problem: "We must ask: if communication for development is the answer, which is the question? Furthermore, if communication for social change is the answer, does the question change? How should we understand development and social change from a communicational perspective? Which is the role of communication in terms of promoting and strengthening forms of citizenship that give priority to citizens as subjects of rights? Which forms of communication have the potential to mobilize a social justice model aimed at reducing inequity among the different social positions? Which public policies are necessary in order to address the threefold challenge of acknowledging differences, righting inequalities and connecting the majority to global networks from a communicational perspective? (García Canclini, 2006) How should we formulate answers to these questions that take into account the different geopolitical scales at play in development processes as 
well as the tensions and contradictions that they impose?” (ibid: 2)

CDSC poses a paradox. On the one hand, it is an approach framed by two terms development and social change- that are not adequate to tackle problems of a sociopolitical nature, in that they lack attention to the logic of neoliberal capitalism and overemphasize micro-level approximations to change, thus disregarding macro-level action such as e.g. the design of public communication policies or the formation of counter-globalization movements. On the other hand, and despite these limitations, CDSC's theoretical and practical resources offer greater possibilities for thinking about communicational matters in sociopolitical terms than other approaches focusing on the non-profit sector, such as social marketing and advertising, or public relations.

In Spain, the influence of the latter approaches led a number of development NGOs to adopting what Erro (2002) qualifies as ‘marketed communication', i.e. a communicational strategy aimed at fundraising that neglects the promotion of transformative social processes. Another dominant trend among Spanish development NGOs was to seek the attention of the mass media through the generation and distribution of news stories. Besides the three apparent approaches to communication identified by Erro (ibid) -the use of publicity to position a development NGO as yet another brand, the use of communication for fundraising, and the provision of news about the NGO's activities and concerns to the mass media- there is another option, linked to CDSC: to promote processes of social transformation that bring together citizens in social networks in order to implement more horizontal and participatory models and communication styles towards the transformation of unfair economic and political orders.

CDSC certainly has a fuzzier outline tan other approaches to communication such as e.g. marketing, which implies both sociopolitical limitations in terms of promoting social justice and more clearly delineated tools and steps, and thus applicability. As noted by expert practitioners Wendy Quarry and Ricardo Ramírez (2009), CDSC implies gray areas of practice somewhat removed from the idealized theoretical frameworks proposed by academia. These gray areas speak to the fact that every organization responds to a concrete reality and must analyze, jointly with the 
community and other relevant social actors, the material opportunities for promoting communicational processes aimed at change and social justice.

\section{The field's implosion}

Since 2010 and to date, CDSC has expanded in Spain at a speed that contrasts with its prior omission and marginalization, to the point that it has become fashionable. Beginning with the Congress of the AE-IC held in 2010, there has been a great amount of attention to the field, previously unseen, in the form of conferences, publications, research projects and online-based interest groups that tackle CDSC. However, rather than understanding this as a booming period or explosion of the field, I suggest it is instead a sign of implosion. According to the Dictionary of the Royal Spanish Academy, implosion is "the action of collapsing inwards with a clamor, which takes place when the internal pressure of the walls of a cavity is lower than external pressure”. This definition characterizes well the current situation of CDSC in Spain: because of the inconsistencies and weaknesses of the field's historical development, its internal pressure is lower than the external pressures, thus leading to implosion.

If we take into account the theoretical parameters for the study of a given scientific community proposed by Martínez Nicolás (2009), we can see that in Spain CDSC has reached an inflection point, as a consequence of growth that is not sufficiently grounded in terms of its scientific production, institutional advancement and epistemological underpinning. The internal weaknesses faced by the Spanish scientific community and the social activists committed to CDSC lead me to speak not of a critical mass, but rather of a mass in a critical situation (paraphrasing Martínez- Nicolás). How this critical situation is tackled through research, theorization and practical action will have a crucial importance in the success, failure, or continued existence of CDSC in Spain. There is potential for change: the ongoing cycle of social mobilization that started in Spain with the 15-M movement in 2011 and worldwide with movements such as Occupy Wall Street provides an opportunity to build socially relevant bridges between researchers and activists -i.e. for 
praxis. Emerging activities on Big Data and Open Data in Spain are being led by an active community of practitioners. Recent trends point to the convergence of hackactivistas, journalists, academics and citizens in the process of social mobilization aimed at circulating data and handing it over to the public (Sampedro and Lobera, 2014). In parallel with the way in which in free software the source code is released to citizens, open data allows the release of information to society in order to empower citizens.

Furthermore, in order to overcome the historical neglect of CDSC at the macro level identified in this paper, it is necessary for government agencies responsible for matters of international cooperation and aid -mainly the Spanish Agency for International Development Cooperation- to promote communication policies. In additon, deficits must be overcome through an understanding of civil society organizations such as NGOs and social movements as potential creators of collective identities through their media practices and the ensuing logic of connective action (Bennet and Segerberg, 2012).

Although the situation is critical, the growing number of researchers and social organizations currently interested in CDSC implies a unique opportunity, previously unseen in the Spanish context. The ongoing process and trends should be monitored over time and evaluated to establish whether such an opportunity is grasped. The challenge is whether a more solid theoretical basis for the field can be developed, based on rigorous and critical empirical research.

\section{References}

Acosta, A. (2011) Buen Vivir: Today's tomorrow, Development, 54 (4): 441-447.

Alfaro, R. (1993) Una comunicación para otro desarrollo. Lima, Perú: Calandria.

Barranquero, A. (2009) State of the art in citizens' communication in Spain, Development in Practice, 19 (4/5): 643-653. 
Barranquero, A. \& Sáez, Ch. (2010) Comunicación alternativa y comunicación para el cambio social democrático: sujetos y objetos invisibles en la enseñanza de las teorías de la comunicación. Congreso AE-IC, Málaga, España, 2010 (paper).

Beltrán, L. R. (1980) A farewell to Aristotle: horizontal communication. Communication, 5 (1): 541.

Burgui, T. y Erro, J. (2003)La comunicación y la educación para el desarrollo en Navarra (19982002). Navarra, Spain: Universidad Pública de Navarra.

Castells, M. (2012) Networks of Outrage and Hope. Social Movements in the Internet Age. Cambridge: Polity Press.

Chaparro, M. (2002) Sorprendiendo al futuro. Comunicación para el Desarrollo e información audiovisual. Barcelona, Spain: Imedea.

Chaparro, M. (2004) Third Sector radio in Spain, Radio Journal, 1(3): 177-192.

Chaparro, Manuel (2009) Comunicación y Desarrollo: retos para un nuevo periodismo, Telos, 81: 27-40.

Available online at: http://sociedadinformacion.fundacion.telefonica.com/url-direct/pdfgenerator?tipoContenido=articuloTelos\&idContenido=2009110208450001\&idioma=es

Chaparro, M.(2012) Viejos y nuevos paradigmas. En Marques de Melo, J.; Gonçalves, E. \& Bizelli, J.L. (coords.), Comunicaçao para o desenvolvimiento. Pensamento e açao (pp. 19-42). Sao Paulo, Brazil: Cultura Académica.

Chaparro, M.(2013) Comunicación y Desarrollo. Mentiras y verdades. Barcelona, Spain: Imedea.

Chaves, I. (coord.) (2012) Comunicación para el Cambio Social. Universidad, sociedad civil y medios. Madrid, Spain: Los Libros de la Catarata.

Cheval, J.J. (1997) Les radios en France: histoire, état et enjeux. Rennes, France: Apogée.

CONGDE (2005) Informe de la CONGDE sobre la percepción social de las ONGD: así nos ven. Madrid, Spain: Congde.

Da Costa, P. (2007) Communicating as One? A look at the past and future of the UN'S 
Communication for Development Round Tables. Glocal Times, 7. Available online at: http:// ojs.ub.gu.se/ojs/index.php/gt/article/view/2523

Díaz Bordenave, J. (1977)Communication and Rural Development. Paris. UNESCO.

Enghel, F. (2011) Communication, development and social change: future alternatives. ICA Conference Proceedings, Boston.

Enghel, F. (2012) Desiguales, diferentes, desconectados. La comunicación para el desarrollo como interrogante. ALAIC Congress Proceedings, Montevideo, Uruguay.

Erlandson, D. (1993) Doing naturalistic inquiry: a guide to methods. London: Sage.

Erro, J. (2001) Las prácticas comunicativas de las ONGD. De la comunicación mercadeada a la construcción de una mirada comunicacional. Directorio de ONGD 2000 (51-72). Madrid, Spain: Congde.

Erro, J. (2002) El trabajo de comunicación de las ONGD del País Vasco. Bilbao, Spain: Hegoa.

Fernández Viso, A. (2012) Historia de una travesía inconclusa: la comunicación para el desarrollo y el cambio social en la investigación y la docencia universitarias en España. CIC, 17: 41-62.

Freire. P. (1970) Pedagogy of the Oppressed. London: Continuum.

García Canclini (2006) Diferentes, desiguales y desconectados. Mapas de la interculturalidad. Barcelona: Gedisa.

Gumucio-Dagron, A. \& Tufte, Th. (eds.) (2005) Communication for Social Change Anthology: Historical and contemporary readings. New Jersey: CFSC.

Gónzalez, H. (2007) Estrategias de Comunicación en las ONG de Desarrollo. Departamentos, funciones e impacto en medios. Cideal:Madrid.

Kaplún, M. (1998) Una pedagogía de la comunicación. Madrid: Ediciones de la Torre.

Jerez, A, Sampedro, V. \& López Rey, J. (2008) Del 0'7 a la desobediencia civil: política e información del movimiento y las ONG de Desarrollo (1994-2000). Madrid, Spain: Centro de Investigaciones Sociológicas.

Lennie, J. and Tacchi, J. (2010) “Evaluating Communication for Development: Trends, Challenges 
and Approaches. Draft Report on a Literature Review and Consultations Conduced for the Project: UN Inter-agency Research, Monitoring and Evaluation Resource Pack for Communication for Development Programs”. New York, UNICEF.mar

Marí, V.M. (2007) Contra la evaporación de la dimensión política de la comunicación. Movimientos sociales, ONG y usos de Internet, Zer, 22, 453-471, http://www.ehu.es/zer/hemeroteca/pdfs/zer22-23-mari.pdf

Marí, V.M. (2011) Comunicar para transformar, transformar para comunicar. TIC desde una perspectiva de cambio social. Madrid, Spain: Editorial Popular.

Marí, V. M. (2013) Participatory communication for development in practice: the case of community media, Development in Practice, 23, (4): 526-538.

Martínez- Nicolás, M. (2009) La investigación sobre comunicación en España. Evolución y retos actuales. En Martínez-Nicolás, M. (coord.), Para investigar la comunicación. Propuestas teórico-metodológicas (pp. 13-52). Madrid, Spain: Tecnos.

Martínez Nicolás, M. y Saperas, E. (2011) La investigación sobre Comunicación en España (19982007). Análisis de los artículos publicados en revista científicas. Revista Latina de Comunicación Social, 66: 101-129.

Mattelart, A. and M. (1998) Theories of Communication. A short introduction. London: Sage.

Max-Neef, M.A., Elizalde, A., \& Hopenhayn, M. (1991) Human scale development: conception, application and further reflextions (Vol.1). New York: Apex Press.

McDonald, K. \& Tipton, T. (1993) Using documents. London: Sage.

McQuail, D. (2010) Mass Communication Theory. London: Sage.

Meda, M. (2010) La Ley UTECA y el Tercer Sector de la Comunicación: comparativa internacional de las fallas de la legislación española audiovisual y respuesta de la sociedad civil. Trabajo Fin de Máster en Comunicación con fines sociales: estrategias y campañas de la Universidad de Valladolid. Valladolid, Spain.

Mignolo, W. (2000) Local Histories/Global Designs: Coloniality, Subaltern Knowledges and 
Border Thinking. Princenton: Princenton University Press.

Mills, W.(1959) The Sociological Imagination. Oxford: Oxford University Press.

Moragas, M. de (2005) Investigación de la comunicación y política científica en España. Ponencia presentada en la Reunión Científica de la Sociedad Española de Periodística (SEP). Santiago de Compostela, Spain.

Moragas, M. de (2011) Interpretar la comunicación. Barcelona, Spain: Gedisa.

Morris, N.(2003) A Comparative Analysis on the Difussion and Participatory Models in Development Communication. Communication Theory, 13 (2),225-248. DOI: 10.1111/j.1468-2885.2003.tb00290.x

Nerfin, M. (ed.) (1977) Another Development: Approaches and Strategies. Uppsala, Sweden: Dag Hammarskjold Foundation.

Nós, E. \& Picazo, D. (2013) Communication and Engagement for Social Justice. Peace Review: A Journal of Social Justice, 25 (3): 343-348.

Obregón, R., Wilkins, K. And Tufte, Th. (2014) The Handbook of Development Communication and Social Change. New Jersey: Wiley-Blacwell.

Ogan, C. et al. (2009) Development Communication: the State of Research in an Era of ICTs and Globalization. Gazette, 71 (8), 655-670.

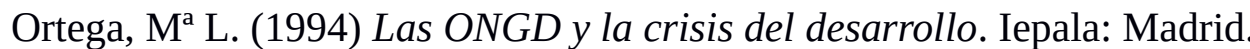

Parés y Maicas, M. (1981) Breu informe sobre la International Association for Mass Communication Research. Análisi, 3, 137-142.

Pascuali, A. (1963) Comunicación y cultura de masas. Caracas, Venezuela: Monte Ávila.

Quarry, W. and Ramírez, R. (2009) Communication for another development. Listening before telling. London: Zed Books.

Richeri, G. (1985) Television from service to business: European tendencies and the Italian case. In Television in transition: papers from the First International Television Studies Conference. London: BFI Pub. 
Sampedro, V.; Jerez, Ariel \& López Rey, J. (2002) ONG, medios de comunicación y visibilidad pública. La ciudadanía ante la mediatización de los mensajes sociales. En Revilla, M. (coord.), Las ONG y la política (pp. 251-285). Madrid, Spain: Istmo.

Santolino, M. (2010) Recuperando la esencia: las ONGD como agentes de comunicación para el cambio social. En Burgui, T. \& Erro, J. (coords.), Comunicando para la solidaridad y la cooperación. Cómo salir de la encrucijada (pp. 221-256). Pamplona, Spain: Foro Comunicación, Educación y Ciudadanía.

Servaes, J. (2007a) Communication for Development: Making a Difference, a WCCD background study. In J. Servaes, World Congress on Communication for Development: Lessons, Challenges and the Way Forward. Washington: The World Bank.

Servaes, J. (2007b) "Harnessing the UN system into a common approach on communication for development”. Paper prepared for the 10th Inter-Agency Round Table on Communication for Development, Addis Ababa, Ethiopia, 12-14 February 2007.

Sierra, F. (2006) Políticas de Comunicación y Educación. Crítica y desarrollo de la Sociedad del Conocimiento. Barcelona, Spain: Gedisa.

Sousa Santos, B. (2009) Una epistemología del Sur. La reinvención del conocimiento y la emancipación social. México: CLACSO/Siglo XXI.

Wallerstein, I. (2004) World-Systems Analysis: An Introduction. Durham: Duke University Press.

Wilkins, K. (2000) Redeveloping Communication for Social Change: Theory, Practice \& Power. Boulder, CO: Rowman \& Littlefield Publishers, Inc. .

Wilkins, K. (2008) Development Communication. In W. Donsbach, The International Encyclopedia of Communication. Blackwell Publishing.

Wilkins, K. (2009) What's in a name? Problematizing communications shift from development to social change. Glocal Times, 13: http://ojs.ub.gu.se/ojs/index.php/gt/article/view/2580 